\title{
Teacher Retention: A Review of Policies for Motivating Rural Basic School Teachers in Ghana
}

\author{
Phinihas Acheampong ${ }^{1}$ \\ Juliana Fosua Gyasi ${ }^{2}$ \\ ${ }^{1,2}$ PhD student, Faculty of Education, School of Educational Technology, Beijing Normal University, China \\ Email:aphinihas@yahoo.com
}

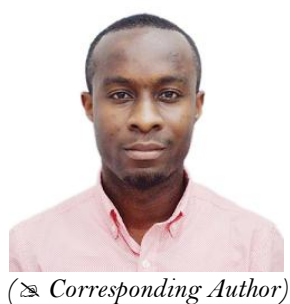

Abstract

The study primarily explored the challenges of teaching in rural basic schools in Ghana. Qualitative research method through semi-structured interviews and document analyses were used as data collection instruments. The participants for the study included six educational field workers which constituted a district education officer (Circuit Supervisor), two head teachers and three classroom teachers. Priority of the findings was highlighted on the provision of accommodation with adequate installation of lighting facility, potable drinking water, and transport facilities such as a vehicle, motorbike and bicycle to ease the living constraints of teachers who serve in underprivileged learning communities. Again, professional development programs were found relevant to encourage and promote teachers working in remote areas. Results of the study shown that rural basic school teachers do not see why they should receive equivalent conditions of service as their peers who teach in urban schools. It is therefore recommended that, about one-third of teachers' salary should be apportioned as additional incentive to motivate teachers who serve in rural basic schools. Again, special student-trainees recruitment strategies should be adopted to recruit potential teachers from underprivileged communities to receive training and serve their people. This can effectively be implemented when the District Sponsorship Scheme Project is restored to enhance better deployment of teachers in underserved schools.

Keywords: Teacher retention, Motivation, Supervision, Rural teachers.

JEL Classification: Education and Research Institutions (Government Policy 128)

Citation | Phinihas Acheampong; Juliana Fosua Gyasi (2019) Teacher Retention: A Review of Policies for Motivating Rural Basic School Teachers in Ghana. Asian Journal of Education and Training, 5(1): 86-92.

History:

Received: 22 October 2018

Revised: 26 November 2018

Accepted: 2 January 2019

Published: 21 January 2019

Licensed: This work is licensed under a Creative Commons

Attribution 3.0 License $(\mathrm{ccc})$ E

Publisher: Asian Online Journal Publishing Group
Contribution/Acknowledgement: Both authors contributed to the conception and design of the study.

Funding: This study received no specific financial support.

Competing Interests: The authors declare that they have no conflict of interests.

Transparency: The authors confirm that the manuscript is an honest, accurate, and transparent account of the study was reported; that no vital features of the study have been omitted; and that any discrepancies from the study as planned have been explained.

Ethical: This study follows all ethical practices during writing.

\section{Contents}

1. Introduction. 87

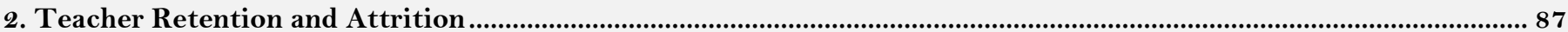

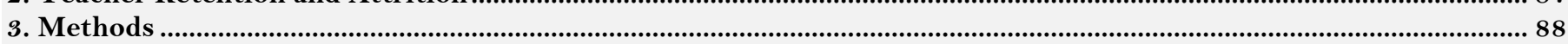

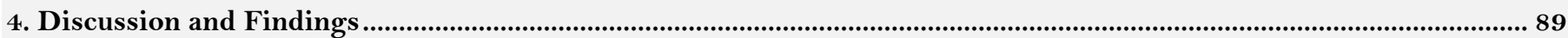

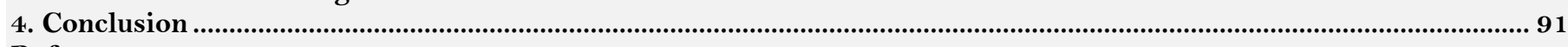

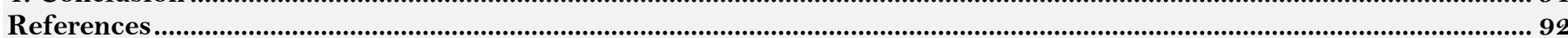




\section{Introduction}

Teacher attrition in basic schools is a global phenomenon which affects the quality of education in Africa. Stakeholders of education have expressed concerns on the rapid rate at which some teachers vacate from the profession and the consistent absenteeism in rural schools. There have been instances where teacher retention policies were quite substantive in sustaining and improving the teaching workforce. It seems that such policies have not fully been implemented to overcome the canker. Though the problem is found country wide, the most alarming cases are seemingly prevalent in the rural areas. The impression is that about $66 \%$ of rural dwellers are partially deprived from having quality education (World Bank, 2014) a situation that is fervently criticized by International organizations' such as World Bank, UNDP (United Nations Development Program), UNESCO (United Nations Education for Scientific and Cultural Organization) and FAO (Food and Agricultural Organization).

The National Education For All (EFA) Review Report in (2014), cites insufficient financial and material resources, poor road networks linking deprived areas, inadequate trained teachers especially in remote and underserved villages, poor credibility of reliable data in schools, frequent intruders of outsiders in educational issues, inadequate school infrastructure and facilities, and indifference in political will power as the major challenging factors of teacher retention in Ghana (UNESCO, 2014). With respect for attaining the EFA and Millennium Development Goals (MDGs) in Ghana, teacher education programs were intensified to nurture qualified teachers and maintained a well-balanced distribution of teachers in all parts of the country. Again, programs such as school feeding, capitation grant (Ministry of Education, 2013; Adam et al., 2016) distribution of free uniforms and exercise books were implemented to enforce the achievement of Strategic Development Plan in 2015.

It must be emphasized that, remarkable improvement has been seen in basic school enrolment, which could be attributed to the implementation of the said policies. In the (Education Sector Performance Report, 2015) the statistical analysis of the Net Enrolment Rate (NER) of the three levels of Ghanaian basic school indicates $82.7 \%$ in Kindergarten, $91 \%$ in primary and $49 \%$ in Junior High School. Comparatively, there has been $27 \%$ increase NER in KG from 2010/2015, 7.4\% in primary education and a steady growth of $1.5 \%$ in JHS (ESPR, 2015).

In order to secure enrolment with meaningful learning, the quality of the teaching workforce should correspond with the enrolment outcome. However, in Ghana, the plight of curriculum implementers who teach in disadvantaged areas are not taken into proper consideration. As a result, such schools are more likely to suffer the consequences of teacher instability, which affects the academic performance of most pupils. Moreover, the very few teachers who accept postings in such dilapidated areas do not utilize the full instructional hours creating vacant classes and underutilized contact hours. Although there is an outstanding teacher retention challenges in basic schools in the whole country, this research seeks to focus on teacher retention problems in rural areas.

The study is meaningful in promoting teacher retention in Ghana. It seeks to bring to light the devastating effect of teacher attrition rate in rural communities. In addition to this, the study endeavors to revive existing policies, which will motivate teacher sustainability. Through the findings of the study, the community and other teacher associations such as GNAT (Ghana National Association of Teachers), NAGRAT (National Association of Graduate Teachers), Non-Governmental Organizations (UNESCO, 2015) Parent Teacher Associations (PTA) and other private business cohorts will see the need to support the government in managing education. It must be noted that all these can be achieved effectively when educational providers and beneficiaries of education recognize the usefulness of knowledge as the bedrock for developing every country.

\section{Teacher Retention and Attrition}

Retention has extensively been used in different ways by a diverse school of thought. From the Dictionary of Merriam-Webster, it is described "as the act or ability to keep or retain something or someone". In the context of teacher education, it refers to the ability of an educational institution to sustain the teaching workforce from the point of recruitment until retirement. These mean educational institutions are not only responsible for recruiting, training and deploying but ensuring the stability of the teaching workforce. For the purpose of the study, teacher stability refers to avoidance of rampant job vacation and unnecessary transfer of teachers from rural to urban schools or from teaching field to another employment. A review on teacher attrition by International Task Force on Teachers for EFA (2010) defines attrition as "all permanent losses of teachers from the teaching profession, for whatever reason". The paper highlighted voluntary resignation and retirement as the two major driving forces for teacher attrition in many countries, which was described as unpredictable and predicable departure.

The impact of teacher attrition is prevalent on high cost of recruiting, training, hiring and professional development, which adversely affect the financial stability of the country. In a broader example, developed countries, such as The United States, spends billions of dollars only to fight the menace of teacher attrition. For instance, The Organization for Economic Cooperation and Development (OECD) reported that an amount of three billion dollars was estimated to have been spent on teacher attrition in the United States (as cited in Karsenti and Collin (2013)). In a similar scenario, the Ministry of Education Science and Sports (2008) disclosed that an amount of $\$ 100,000,000$ was budgeted to cater for the cost of teacher absenteeism problems alone in Ghana.

\subsection{Challenges of Teaching in Rural Schools}

According to FAO et al. (2003) rural areas are defined by certain specific features. The document emphasizes that rural areas have low human settlement, which has a population of about 5-10,000 people with the main occupation being agriculture. Moreover, rural areas are detached from urban areas with long distances and most errands are embarked with high transactional cost. These features of rural areas do not differ from rural areas in Ghana, but most typical rural areas are scattered villages separated from one another. Ghana has about 26.76 million populations in which $66 \%$ are dwellers of remote areas. Schools in such areas are built within the center of the scattered villages to allow equal accessibility. Pupils cover distances more than 45 minutes by foot to enable them reach some schools to acquire knowledge. The problem is that it is sometimes difficult to reach school going children living in remote areas for educational purposes (WB, 2008). 
Basic necessities of life such as water, food and shelter are difficult to attain in remote dwelling schools. Occupants of rural areas build their houses most often with the aim of providing shelter for their families. Migrant workers like teachers and nurses find accommodation challenging in such places. Few workers are known to reside in government or state houses such as the Social Security and National Insurance Trust (SSNIT) apartment in urban areas. However, in the rural areas, government has made little effort to provide accommodation for workers especially teachers. This makes teachers find it difficult to get standard lodging apartment. The very few available houses for rent are mostly unconducive for teachers' habitation, coupled with lacking facilities such as electricity. In addition to this phenomenon, road networks to most rural areas are very deplorable making teachers who want to attend school from distant towns impossible (ESPR, 2015). World Bank report in 2008 confirms that issues of this nature have proven government effort futile in deploying and sustaining teachers in remote areas.

It is clear that such poor working environment in rural areas creates huge setbacks for teacher retention. Novice teachers who accept postings in rural areas find their way out within a couple of one or two years. Taylor and Mulhall (2001) contend that remote areas create limited prospects for job development. Teachers become more isolated and are detached from workshops and trainings that improve their professional development. In order to improve the quality of education, there is the need for adequate teacher preparation program, which should focus on both teaching pedagogy and content (Mulkeen et al., 2007). The paper further asserts that workshops and orientation programs such as in-service program enable upgrading of untrained teacher's qualifications, provides short-term courses on contents and, teaching skills and provide masters' degree courses for qualified teachers. However, the significance of in-service programs to motivate teachers to remain in the teaching profession should also consider the trade-offs and implications of teacher supply and finances (UNESCO \& IICBA, 2016). For example, in-service program opportunities for teachers resonate with promotions (salary adjustment) and migration of teaching positions.

Further, research in this field has shown that, a greater percentage of teachers has shown preference for teaching in urban schools which are more effective in teaching and learning practices than in rural schools. This is due to the fact that life and job satisfaction in urban schools are far better than rural areas (Akyeampong and Lewin, 2002). Loeb et al. (2012) revealed four key findings of the relationship between school effectiveness through recruitment, assignment, development and retention of teachers. The paper contends that schools that are effective attract and hire quality teachers, receive equitable distribution of teachers, improve job professional development (Hedges, 2000) and retain quality teachers. Based on the assertions of Loeb et al. (2012) it is clear that rural schools in Ghana do not have certain characteristics which attract potential teachers. However, teachers in rural schools become less and less effective due to the absence of in-service training and subsequent workshops, which enhance professional development.

\section{Methods}

The study employed semi-structured interview as a qualitative research designed for data collection. The researcher prepared an interview guide, which served as an outline or framework for adequate questioning and response. The interview process was made flexible to solicit in-depth response from the participants (Bryman, 2008). Though the researcher adopted semi-structured interview, questions were not strictly followed as structured in the outline. Bryman recommends that, researchers who pick on responses of their interviewee receive detailed description of both anticipated and unanticipated responses. This paved way for thorough retrieval of information, which was relevant for the study as participants unfolds their story.

Because the concept of teacher retention is an absolute phenomenological study, the researcher guided participants to describe in rich detail the context of the challenges rural teachers encounters in remote areas. This revealed the particularity and complexity of human experiences in the context of teacher retention in Ghana (LeCompte and Preissle, 1993).

According to some renowned scholars in the field of qualitative research, purposefully selecting participant for data collection is regarded as the best sampling approach (LeCompte and Preissle, 1993; Patton, 2002). Patton (2015) also suggests that purposeful sampling provide the means of "selecting information-rich cases to study, cases that by their nature and substance will illuminate the inquiry question being investigated" (pp. 264). This sampling approach was adopted by the researcher to gain detailed insights and understanding of selected participants in the study.

Having this in mind, the researcher selected 6 participants from one (1) deprived district out of the seventy-five (75) underprivileged districts in Ghana. The participants for the study consisted of males and females who were field practitioners as teachers and educational administrators. They included two rural basic head teachers from different schools, one district education officer (Circuit Supervisor) and three classroom teachers who have served for more than three years in rural basic school. This was done to gain the general perception and experience of the challenges of teaching in remote schools and the possible strategies that can enhance teachers' sustainability in such places. In all, participants were interviewed through face-to-face interaction. Each interview session lasted for at least 45 minutes. To enhance confidentiality and anonymity, names of participant were pseudonym with alphabets starting from 'A' to 'F'.

Again, a review of the document was done to serve as secondary source of data, which enhanced analysis of policies under the Ministry of Education in teacher recruitment, training, deployment and retention. This document includes national and international publications (UNESCO, GES, OECD, MOE etc.) reports on education projects and teacher development.

For the purpose of data analysis, the researcher gathered responses from participant through field notes, tape recordings and jottings. A complete reading and listening of the text and audio was done which enhanced easy coding of the text. The data was categorized through mind-maps by which respective themes were derived for further interpretation (Hycner, 1985). Participants were given the scripts to read through after the coding to verify if they had not been misinterpreted. This was done to ensure that responses provided by the participant were valid and the data gathered were reliable respectively (Patton, 2015). 


\section{Discussion and Findings}

Three main themes were developed from the interview and document analysis conducted during the study. These themes are: categories of basic school teachers in Ghana, challenges of rural teachers and strategies for mitigating teacher attrition in rural basic schools.

\subsection{Category of Basic School Teachers}

According to the document analysis, Ghana has undertaken several teacher education reforms to improve the quality of education in the country. The category of teaching force which has been built over the years include 4year Certificate 'A' Teacher, Certificate 'B' Teacher, 2-Year Post-Secondary Certificate 'A' Teacher, 3-Year Post Secondary Certificate 'A' Teacher, 2-Year Specialist/3-Year Diploma Teacher, The Graduate teacher, National Service Personnel and the Pupil Teacher (Agbeko, 2007).

It must be clarified that in Ghana, there are two main categories of basic school teachers which form the workforce for the education service. The trained teachers have received formal training in Colleges of Education, Distance or Sandwich programs while the untrained teachers normally referred as pupil teachers are those who have been recruited from high school, polytechnics and universities to teach but do not have any formal teaching training. Again, trained teachers employed by government of Ghana are permanent professional teachers while the untrained teachers are recruited as temporal workers whose contract are renewable annually based on job satisfaction, efficiency and existing vacancies in the service. Participant 'A' confirmed that;

My school has 14 teaching staff with 7 trained teachers while the rest are untrained. The untrained teachers were recruited with high school certificate while the trained teachers were posted to the school directly after completing teacher training college.

In Ghana, the current recommended minimum qualification for teaching in basic school is diploma certificate. This is as a result of the upgraded teacher training colleges into diploma awarding institutions since 2000. This has immensely attracted and increased the teacher supply in the country. Again, further policies were implemented to enable Cert 'A' and untrained teachers to upgrade their qualification to diploma level. Programs such as Sandwich courses, Untrained Teachers Diploma in Basic Education (UTDBE) and other Distance Educational programs aimed at improving teacher reputation, status and retention especially in rural areas (Asare-Danso, 2014). Participant 'A' who heads one of the rural schools confirmed that;

Pupil teachers in my staff are hastily pursuing further studies to upgrade their professional status to at least diploma level. This was as a result of the government intervention to withdraw untrained teachers who had not been formally nurtured on teaching pedagogy. I must confess it is a good initiative to improve the quality of education. The problem is that most pupil teachers who successfully complete their program are unwilling to work in the rural areas. The rural schools end up losing their few teachers to the semi and urban area schools.

\subsection{Indicators for Public Basic Schools in Ghana, by Levels}

The table below depicts teacher indicators in public basic schools, by levels. Results from the three levels show that, percentage of trained teachers has improved significantly over time from $32 \%$ in $2009 / 10$ to $61.7 \%$ as stipulated in the ESPR (2015). In the ESPR (2013) 95\% of teacher retention were estimated to be achieved nationwide. It can be inferred from the statistics that about one third of teacher's projection has not yet been accomplished. This might be due to factors such as the withdrawal of trainees' allowance, lack of incentivized schemes for rural teachers and poor remuneration. Again, statistics on teacher deployment in basic education sector indicated that Kindergarten schools suffer high attrition rate of trained teachers ( $47 \%)$ than primary (56\%) and JHS $(78 \%)$.

Table-1. Teacher Indicators for Public Basic Schools in Ghana by Levels

\begin{tabular}{l|l|l|l|l|l|l}
\hline \multicolumn{2}{|l|}{ National } & \multicolumn{3}{l}{ Deprived districts } \\
\hline KG & $2012 / 13$ & $2013 / 14$ & $2014 / 15$ & $2012 / 13$ & $2013 / 14$ & $2014 / 15$ \\
\hline PTR & 37 & 34 & 35 & 54 & 52 & 52 \\
\hline PTTR & 72 & 62 & 56 & 159 & 138 & 112 \\
\hline$\%$ Trained Teachers & 52 & 55 & 61.7 & 34 & 37 & 47 \\
\hline Primary & $2012 / 13$ & $2013 / 14$ & $2014 / 15$ & $2012 / 13$ & $2013 / 14$ & $2014 / 15$ \\
\hline PTR & 33 & 32 & 34 & 39 & 38 & 40 \\
\hline PTTR & 48 & 46 & 45 & 78 & 77 & 72 \\
\hline$\%$ Trained Teachers & 69 & 70 & 75 & 50 & 50 & 56 \\
\hline JHS & $2012 / 13$ & $2013 / 14$ & $2014 / 15$ & $2012 / 13$ & $2013 / 14$ & $2014 / 15$ \\
\hline PTR & 16 & 15 & 16 & 20 & 19 & 20 \\
\hline PTTR & 19 & 18 & 18 & 27 & 27 & 26 \\
\hline$\%$ Trained Teachers & 84 & 84 & 87.8 & 7 & 72 & 78 \\
\hline Source: Adapted from ESPR $(2015)$ & & & & \\
\hline
\end{tabular}

\subsection{Challenges of Rural Teachers}

The deplorable nature of rural environment makes rural teaching unsatisfactory. The interview conducted revealed accommodation, electricity, market, health care facility, network (internet), potable drinking water and feeling of isolation as major factors of teacher attrition in rural areas. Participant 'B' commented that,

The major challenge of my school is accommodation. We have teachers' quarters (bungalow) which has five single bedrooms that is supposed to house 14 teaching staff. Due to inadequacy of lodging places most of the teachers reside in towns which are more than $5 \mathrm{~km}$ away from the school.

Some of the rural schools do not have accommodation for teachers at all. This leads to excessive absenteeism and loss of contact hours, which eventually affect the quality of education in the country. The case becomes exacerbated as a result of the deplorable nature of the road. Participant D confirmed, 
Most drivers do not want to ply their vehicles on such roads. It therefore becomes difficult for us to attend school regularly and punctually. The situation looks 'okay' for those who use motorbikes as a means for transportation to school. On the other hand, the cost is unbearable due to high cost of maintenance and exorbitant fuel prices.

Comparatively, most health care facilities built in rural areas have quarters (bungalows) attached to the facility, which provides shelter for health practitioners. Why is the case different from teacher education? When will basic school teachers in Ghana be considered for such labor incentives? Until now, state housing project for public servants in the country has not been expanded to cover workers in urban areas not to talk of public rural servants. The very few housing projects initiated with the 'tax payers' money have been abandoned uncompleted under the mercy of sun and rain (Example, the affordable housing project initiated under the auspices of Ex-President John Agyekum Kuffour in 2004).

Some rural teachers were asked if their financial contribution towards Teachers Fund in respective teacher associations is sufficient for securing accommodation. Participant ' $F$ ' responded that;

The Ghana National Association of Teachers (GNAT) and Coalitions of Concern Teachers Association are the two main teacher associations in Ghana for basic education. Efforts have been made by GNAT for example to support teachers with housing facilities since the establishment of Teachers' Fund in 1998. However, these proposals have not provided the teacher with viable financing options to enable them to participate.

The findings of the study are consistent with EFA report which cited insufficient financial and material resources, poor road networks linking deprived areas, inadequate trained teachers especially in remote and underserved villages, poor credibility of reliable data in schools, inadequate school infrastructure and facilities, and indifference in political will power as the major challenging factors of teacher retention in Ghana (UNESCO, 2014).

\subsection{Challenges of Rural Head Teachers}

Findings from the study indicated that rural basic school principals face uncountable obstacles in the process of discharging their duties. Administratively, heads of rural basic schools complain bitterly of high absenteeism and lateness on the part of both students and teachers. According to the response of participant ' $\mathrm{F}$ ', rural teachers' use of flimsy excuses such as attending to hospital, withdrawing money from the bank, going for lectures, inability to get transport (car) to school as an excuse to absent themselves. Education Sector Performance Report in 2013 gives statistical overview of teacher attendances in 41 deprived districts.

Table 2 Teacher attendances at the district level (4.1 deprived districts)

\begin{tabular}{l|l|l|l}
\hline & KG (\%) & Primary (\%) & JHS (\%) \\
\hline Overall attendance rate & 78 & 79 & 82 \\
\hline Average district attendance rate & 78 & 79 & 81 \\
\hline Highest district attendance rate & 90 & 90 & 91 \\
\hline Lowest district attendance rate & 65 & 66 & 58 \\
\hline
\end{tabular}

The figure above illustrates the attendance rate of 41 deprived districts in Ghana. It can be deduced that the average attendance rate of teachers increased in relation to increasing levels of education. Teachers' attendance rate in $\mathrm{KG}(78 \%)$, Primary $(79 \%)$ and JHS $(82 \%)$ has a rough average of $20 \%$ absenteeism over time. This confirms the response given by headmaster 'B' which stipulates that:

High absenteeism occurs in my school usually during the beginning and ending of the week, Mondays and Friday's to be precise. At least in every week, three to four teachers of my staff absent themselves from school. Due to this rampant absenteeism, scheme of work is inefficiently completed. Perhaps, it affects the academic performance of the school.

It is clear from this point that the lowest deprived district attendance rate of 58\% in Junior High School (JHS) is a transparent indication of high absenteeism rate in rural basic schools in Ghana which adversely affect the academic performance of students. What is unbeknown to educational stakeholders is that such negative behaviors have greater influence on the overall performance of Basic Education Certificate Examination (BECE).

Table 3. BECE 'above average' rates by deprived and non-deprived districts, 2014

\begin{tabular}{l|l|l|l|l}
\hline District Type & Subjects & \multicolumn{3}{l}{} \\
\hline & English (\%) & Mathematics (\%) & Science (\%) & Social Studies (\%) \\
\hline Deprived districts & 8.3 & 13 & 10.3 & 9.4 \\
\hline Non-deprived districts & 26.3 & 26.3 & 25.4 & 24.9 \\
\hline National & 23 & 23 & 22 & 23 \\
\hline Source: ESPR (2015) &
\end{tabular}

Figure 1.2 indicates the 'above average' rates of BECE statistics of deprived and non-deprived districts in Ghana. From the analysis, it can be construed that non-deprived districts with adequate and qualified teachers perform better than deprived districts. This might be due to various factors such as high retention rate in the urban schools. Perhaps, the working environment is conducive with facilities such as stable electricity supply, availability of Internet, accommodation, and portable drinking water. Loeb et al. (2012) confirms that schools with favorable working conditions are capable of attracting quality teachers. This affects the quality of education in non-deprived districts as exhibited on the table.

\subsection{Salary and other Incentives}

Several packages attract and retain teachers to teach in rural basic schools. Distribution of solar lamps, bicycles and motorbikes motivate teachers to accept postings and transfers to rural areas (MoE, 2015). Again, in 2001 the government of Ghana instituted district sponsorship scheme, which was meant to support (fund) teacher trainees to attract and retain them to rural areas. This policy committed novice teachers to accept postings to serve their respective sponsored district for a minimum period of three years (ITFT, 2010). However, sponsored teachers were made to refund the sponsorship when they decline postings. In effect, the policy promoted balanced distribution of 
teachers in both rural and urban schools. The policy has failed in recent years due to the financial constraint of the country. As confirmed by participant 'C' (Education officer):

Since the cancellation of district sponsorship scheme, deployment of rural teachers hasn't been flexible. Novice teachers feel uncommitted under any binding laws to serve in a rural school. As a District Education Office, one of our policies is to post teachers who are fresh from college to serve in remote areas for the first three years. Contrary, due to lack of motivating packages, teachers are unwilling to accept postings. The worst of it all is the recent withdrawal of trainee allowances in 2015. Most of them complain motivationally cheated for sponsoring their own education while compelled to serve in an underserving environment.

A report released by GNAT/TEWU (GNAT/TEWU of Ghana Trade Union Congress, 2009) on Policy Recommendations for Achieving EFA emphatically state that, rural teachers should be given additional $40 \%$ monetary incentives as a motivation. It is intriguing to note that the policy has not been considered for implementation since 2009. However, there are successful stories of sister African countries like Botswana, Uganda, Lesotho, Zambia, and Gambia where their governments pay additional allowance to teachers in 'hardship schools' to improve teacher's retention (ITFT, 2010).

\subsection{Challenges of Educational Officers: Influence of Opinion Leaders}

Furthermore, District Education Office also faces the problem of interference from the opinion leaders in the society. Favoritism and nepotism practices have become a norm in our society today. Teacher trainees who are sent to deprived areas are able to lobby their way out through some educational officers, chiefs, and other dignitaries to change their undesired posting. A district Circuit Supervisor (CS) commented:

At the moment, I have a case where one teacher posted to a remote area in my circuit has been reposted to a town (urban area) through the influence of an opinion leader in the community. Lots of such cases occur at the district level in the process of deploying teachers. This causes interruption of teacher stability and perhaps demeans the work of human resource personal in charge of postings. Also, there are sometimes internal manipulations such as acceptance of bribes from trainees in order to be posted in urban schools.

\subsection{Poor Supervision}

Findings from the study indicated that there are poor monitoring and supervision by the district education officers. Trekking officers find it cumbersome to visit schools for supervisory purposes due to lack of a mobility facility. A district education officer said:

Since three years ago (2013), trekking officers in my district have not received supervisory allowance. We use our scanty salary for transportation to supervise teachers in rural areas. Honestly, due to lack of financial support the rate at which supervision should be embarked is very low compared with some years ago. Teachers are therefore not well monitored in their school attendance and delivery of lessons. I believe this go a long way to affect the academic success of the students living in such places.

Again, it was realized from the study that, supervisors should visit schools within their district for not less than 12 times in a term. But due to mobility challenges, supervision occurs twice in a term, which usually takes place at the beginning and ending of the term especially in the rural basic schools.

\subsection{Teacher Retention: The Way Forward}

Scrapped allowances of trainees should be restored to attract prospective students to attend teacher training colleges. Though, teacher trainees are self-funded momentarily, but the issue of endangering future enrolment has fully not been considered. For instance, prospective students are more likely to value attaining university degree than college diploma. The reason is that students who are eligible to enroll in teacher colleges similarly qualify for four-year university degree program. It presumably makes no sense to spend their scanty resources on the former which has a low prestige in terms of value of certificate and job opportunities.

Again, the District Education Office should improve on induction and mentoring programs for novice teachers. Mentoring programs, for example, help fresh teachers to adapt easily to their new environment especially in rural areas. The In-Service Educational Training (INSET) programs should be reinforced to help develop teachers' professional competencies. If teachers in rural schools achieve job satisfaction with respect to their professional development which is equivalent to their counterpart in urban areas, they will be more likely to retain in rural schools.

Moreover, District Sponsorship Schemes should be revisited to commit sponsored teachers to serve for at least three to five years in their first postings before transfers can be granted.

Allowances due for supervision should be paid on time to enhance frequent monitoring of rural teachers' attitude towards work by district supervisors. Education officers should refrain from bribery and corruption attitude, which impedes effective deployment of teachers.

Rural teachers should be given special recognition such as awards and promotion to motivate their service in deprived schools. Education officers should make sure that study leave is granted to deserving teachers who merit it.

\section{Conclusion}

Several efforts have been done to sustain and improve teacher retention in Ghanaian basic schools but other factors impede teachers' interest to retain in the profession. There is high attrition and absenteeism rate due to dissatisfaction of teachers especially those serving in underserved villages. This goes a long way to affect the lives of innocent children who reside in dilapidated learning environment. To promote teachers job efficiency in rural areas, the government has to consider making the teaching service attractive by providing accommodation, transport for teachers and supervisors, incentives (salary), restoration of district sponsorship schemes and teacher trainees' allowances. These policies when implemented fully will re-enforce the achievement of Education 2030 
Agenda which seeks to "Ensure inclusive and equitable quality education and promote life-long learning opportunities for all' (World Education Forum, 2015).

\section{References}

Adam, S., D. Adom and A.B. Bediako, 2016. The major factors that influence basic school dropout in rural Ghana: The case of Asunafo South District in the Brong Ahafo Region of Ghana. Journal of Education and Practice, 7(28): 1-8.

Agbeko, J.K., 2007. Pre - service teacher training and its challenges: The current situation in Ghana. NUE Journal of International Education Cooperation, 2: $73-80$.

Akyeampong, K. and K.M. Lewin, 2002. From student teachers to newly qualified teachers in Ghana: Insights into becoming a teacher. International Journal of Educational Development, 22(3-4): 339-352. Available at: https://doi.org/10.1016/s0738-0593(01)000591.

Asare-Danso, S., 2014. Effects of educational policies on teacher education in Ghana: A historical study of the Presbyterian college of education. International Journal of Humanities and Social Science, 4(6): 57-65.

Bryman, A., 2008. Social research methods. 3rd Edn., New York: Oxford University Press.

Education Sector Performance Report, 2015. Ministry of education, Ghana. [Accessed 15/11/2016].

ESPR, 2013. Ministry of education, Ghana. Available from www.moe.gov.gh/assets/medi/docs/FinalEducationSectorReport-2013.pdf [Accessed 17/11/2016].

FAO, UNESCO and IIEP, 2003. Education for rural development: Towards new policy responses. Available from http://unesdoc.unesco.org/images/0013/00 1329/132994e.pdf [Accessed 18/10/2016].

GNAT/TEWU of Ghana Trade Union Congress, 2009. Teacher attrition in Ghana; results of a questionnaire survey.

Hedges, H., 2000. The importance of posting in becoming a teacher in Ghana, a discussion paper. Centre for International Education University of Sussex Institute of Education Multi - Site Teacher Education Research Project (MUSTER).

Hycner, R.H., 1985. Some guidelines for the phenomenological analysis of interview data. Human Studies, 8(3): 279-303. Available at: https://doi.org/10.1007/bfoo 142995.

International Task Force on Teachers for EFA, 2010. Teacher attrition in Sub-Saharan Africa: The neglected dimension of the teacher supply challenge, a review of literature. http://www.teachersforefa.unesco.org/v2/phocadownload/teacher_attrition.pdf.

Karsenti, T. and S. Collin, 2013. Why are new teachers leaving the profession? Results of a Canada-wide survey. Education, 3(3): 141-149.

LeCompte, M.D. and J. Preissle, 1993. Ethnography and qualitative design in educational research. New York: Academic Press, Inc.

Loeb, S., D. Kalogrides and T. Béteille, 2012. Effective schools: Teacher hiring, assignment, development, and retention. Education Finance and Policy, 7(3): 269-304. Available at: https://doi.org/10.1162/edfp_a_00068.

Ministry of Education, 2013. Education Sector Performance Report, Ghana. Available from https://new-ndpcstatic1.s3.amazonaws.com/pubication/2013+Education+Sector+Performance+Report.PDF [Accessed 17/11/2016].

Ministry of Education Science and Sports, 2008. Preliminary education sector performance report. Ghana, Accra: Ministry of Ed ucation.

MoE, 2015. Education Sector Performance Report, Ghana. Available from https://new-ndpcstatic1.s3.amazonaws.com/CACHES/PUBLICATIONS/2016/03/22/Education+Sector+Performance+Report+(ESPR)+2015_Fi nal.pdf [Accessed 15/11/2016].

Mulkeen, A., D.W. Chapman, J.G. DeJaeghere and E. Leu, 2007. Recruiting, retaining, and retraining secondary school teachers and principals in Sub-Saharan Africa. World Bank Working Paper No. 99. Washington, D.C.

Patton, M.Q. 2002 Qualitative research \& evaluation methods. 3rd Edn., Thousand Oaks, CA: Sage Publications.

Patton, M.Q., 2015. Qualitative research \& evaluation methods. 4th Edn., Thousand Oaks, CA: Sage Publications.

Taylor, P. and A. Mulhall, 2001. Linking learning environments through agricultural experience-enhancing the learning process in rural primary schools. International Journal of Educational Development, 21(2): 135-148. Available at: https://doi.org/10.1016/s07380593(00)00036-5.

UNESCO, 2014. National EFA 2015 review report: Ghana country report. Available from unesdoc.unesco.org/ark:/48223/pfooo0231429 [Accessed 14/11/2016].

UNESCO, 2015. World Education Forum, 2015 Final Report. Available from http://www.unesco.se/wp-content/uploads/2015/06/Worldeducation-forum-KOREA.pdf [Accessed 10/12/2016].

UNESCO \& IICBA, 2016. Teaching policies and learning outcomes in Sub-Saharan Africa Issues and Options, ECA Compound, Addis Ababa, Ethiopia.

WB, 2008. Teachers for rural schools: Experiences in Lesotho, Malawi, Mozambique, Tanzania, and Uganda. Washington, DC 20433: The World Bank, 1818 H Street, NW.

World Bank, 2014. The World Bank Annual Report 2014. Washington, DC. C World Bank. Available from https://openknowledge.worldbank.org/handle/10986/20093 License: CC BY-NC-ND 3.o IGO.

World Education Forum, 2015. Final Report. United Nations Educational, Scientific and Cultural Organization, 7, place de Fontenoy, 75352 Paris 07 SP, France. Available from http://unesdoc.unesco.org/images/0024/002437/243724e.pdf [Accessed 24/07/2016]. 